Article

\title{
Contamination of Surface Water and River Sediments by Antibiotic and Antiretroviral Drug Cocktails in Low and Middle-Income Countries: Occurrence, Risk and Mitigation Strategies
}

\author{
Pius Kairigo ${ }^{1, * \mathbb{C}}$, Elijah Ngumba ${ }^{2}$, Lotta-Riina Sundberg ${ }^{1,3}$, Anthony Gachanja ${ }^{2}$ and \\ Tuula Tuhkanen ${ }^{1}$ \\ 1 Department of Biological and Environmental Science, University of Jyväskylä, P.O. Box 35, FI-40014 \\ Jyväskylä, Finland; lotta-riina.sundberg@jyu.fi (L.-R.S.); tuula.a.tuhkanen@jyu.fi (T.T.) \\ 2 Department of Chemistry, Jomo Kenyatta University of Agriculture and Technology, P.O. Box, \\ 62000-00200 Nairobi, Kenya; engumba@jkuat.ac.ke (E.N.); angachanja@jkuat.ac.ke (A.G.) \\ 3 Nanoscience Center, University of Jyvaskyla, P.O. Box 35, FI-40014 Jyväskylä, Finland \\ * Correspondence: pius.k.kairigo@jyu.fi
}

Received: 31 March 2020; Accepted: 10 May 2020; Published: 13 May 2020

\begin{abstract}
Presence of antimicrobial cocktails in the hydrological cycles is of interest because of their potential to mediate antimicrobial resistance within the natural environment. In this study, we determined the concentrations of selected antibiotics and antiretroviral drugs (ARVDs) in wastewater treatment plant (WWTP) effluent, effluent suspended particulate matter (SPM), surface waters and river sediments in Kenya in order to determine the extent of pollution within the sampled environment. Target analysis for the most common antibiotics and ARVDs was done. Sulfamethoxazole (SMX), ciprofloxacin (CIP), trimethoprim (TMP), norfloxacin (NOR), zidovidine (ZDV), lamivudine (3TC) and nevirapine (NVP) were analyzed using LC-ESI-MS/MS. Effluent aqueous phase had concentrations ranging between $1.2 \mu \mathrm{g} \mathrm{L}^{-1}$ to $956.4 \mu \mathrm{g} \mathrm{L}^{-1}$ while the effluent SPM showed higher concentrations, ranging between $2.19 \mathrm{mg} \mathrm{Kg}^{-1}$ and $82.26 \mathrm{mg} \mathrm{Kg}^{-1}$. This study shows emission of active pharmaceutical ingredients (APIs) from WWTP to the environment mainly occurs via the SPM phase, which is usually overlooked in environmental analyses. Concentrations in surface waters and river sediments ranged between $1.1 \mu \mathrm{g} \mathrm{L}^{-1}$ to $228 \mu \mathrm{g} \mathrm{L}^{-1}$ and $11 \mu \mathrm{g} \mathrm{Kg}{ }^{-1}$ to $4125 \mu \mathrm{g} \mathrm{Kg}^{-1}$ respectively. ARVDs occurred at consistently higher concentrations than antibiotics in both the aqueous and solid samples. The wastewater treatment plants and lagoons where sludge degradation should occur, are sources of active pharmaceutical ingredients (APIs) including transformational products, nutrients and organic matter that are released back to the aqueous phase.
\end{abstract}

Keywords: wastewater; antibiotics; antiretroviral drugs; antimicrobial resistance; suspended particulate matter; sediments

\section{Introduction}

Pollution by pharmaceutical micropollutants is an emerging area of concern. The effect of cocktails of active pharmaceutical ingredients (APIs) to non-target organisms is largely unknown [1]. Cocktails of APIs and their active metabolites enter the environment due to incomplete removal by wastewater treatment plants (WWTPs) after human and veterinary use. Indeed, centralized wastewater treatment plants are point sources of emerging micropollutants, especially active pharmaceutical ingredients (APIs) into the environment [2]. This happens because pharmaceuticals are not completely metabolized in the body and are excreted in urine and fecal matter, as either parent compounds 
or as pharmacologically active metabolites [3-6]. In water-based sanitation, the active ingredients and their metabolites undergo dilution with large volumes of water as they are flushed down the drain, where they mix with other household chemicals and personal care products. Household, hospital and industrial wastewater as well as a runoff water mix and are channeled into the centralized WWTPs. Dilution of the organic micropollutants to very low concentrations (ng $\mathrm{L}^{-1}$ or below) occurs, which cannot be effectively removed from the WWTP, making them ubiquitously present in the water bodies [7]. Pseudo-persistent APIs in the environment have the potential to mediate antimicrobial resistance among the environmental pathogenic microorganism [8]. Effluent from healthcare facilities, WWTPs, pharmaceutical and other industries-especially in low- and middle-income countries-is insufficiently regulated [9]. WWTPs are beneficial for public health; however, they act as sinks to important nutrients such as phosphorus and nitrogen as well as minerals. In wastewater, plants where the activated sludge removal, treatment and discharge into landmines or fields occurs, the flow of adsorbed recalcitrant micropollutants happens between aqueous phase to terrestrial systems. Wastewater treatment plants such as lagoons, anaerobic and aerobic ponds and trickling filters in which the excess sludge is meant to decompose, are where the nutrients and recalcitrant matter including micropollutants are desorbed and released from the sludge into the effluent and eventually into the receiving water bodies, where they potentially cause eutrophication and stress to aquatic organisms [10,11].

Previous research work on this topic has focused on the aqueous phase, but here we also report data on occurrence of active pharmaceutical ingredient (API) cocktails in suspended particulate matter (SPM) and river sediments. This study was aimed at assessing the levels of selected common antibiotics; sulfametoxazole (SMX), ciprofloxacin (CIP), trimethoprim (TMP), norfloxacin (NOR) and antiretroviral drugs; zidovidine (ZDV), lamivudine (3TC) and nevirapine (NVP) in the effluent, SPM surface water and river sediments of selected sampling sites in Kenya.

\section{Materials and Methods}

\subsection{Study Area and Sample Collection}

Effluent surface water grab and river sediment upstream and downstream of the effluent discharge point from the wastewater treatment plant (WWTP) was collected in Machakos town, Kenya. The WWTP Machakos in Machakos employs waste stabilization ponds for wastewater treatment. Machakos town is the administrative town of the larger Machakos County. The Machakos town constituency has a population of 50,753 , with a WWTP serving $7.6 \%$ of the population while $13.1 \%$ and $55.2 \%$ of the population use septic tanks and pit latrines, respectively [12].

Two sampling campaigns in January and September 2019 were carried out. September is usually a very dry month and most arid and semi-arid areas suffer drought, affecting the flow rates into the treatment plant as well as in the rivers. The river Mitheu, which receives the effluent from the WWTP, was almost drying up and the flowing waters were contaminated with raw sewage judging by the odor and appearance. Generally, the water volumes in the rivers were significantly decreased during the September sampling as compared to the January sampling. The physicochemical characteristics of the samples are shown in Table 1. The effluent composite sample was constituted by combining the eight hourly grab samples into a large container from which duplicate 1-L representative samples were drawn and taken to the laboratory for further processing. Duplicate grab 1-L river water samples were collected at approximately $500 \mathrm{~m}$ upstream and downstream of the effluent discharge point. River sediment samples were collected at similar points corresponding to the aqueous samples and dried indoors at room temperature $\left(25^{\circ} \mathrm{C}\right)$. The sample collection protocols are described in detail in our previous publication [13]. The suspended particulate matter was obtained by successive filtration of $100 \mathrm{~mL}$ of the aqueous sample through a Whatman GF/D $(2.7 \mu \mathrm{m})$ and GF/F $(0.7 \mu \mathrm{m})$ filter papers. The filter papers were dried at room temperature $\left(25^{\circ} \mathrm{C}\right)$ and processed similarly to the sediment samples. 
Table 1. Psychochemical characteristics of the effluent and surface water samples showing the $\mathrm{pH}$, temperature, electrical conductivity, total dissolved solids and total suspended solids. ES = electrical conductivity, TDS $=$ total dissolved solids and TSS $=$ total suspended solids.

\begin{tabular}{cccccc}
\hline Sample & $\mathbf{p H}$ & Temp $\left({ }^{\circ} \mathbf{C}\right)$ & EC $(\mathbf{d S} / \mathbf{m})$ & TDS $(\mathbf{p p m})$ & ${\text { TSS }\left(\mathbf{m g ~ L}^{-1}\right)}^{-1}$ \\
\hline Effluent & 7.88 & 30.2 & 5610 & 3.73 & 72.8 \\
\hline Surface water & 6.36 & 27.6 & 1140 & 2.86 & 66.4 \\
\hline
\end{tabular}

\subsection{Chemicals and Standards}

All pharmaceutical standards and corresponding isotope-labelled internal standards were of $>99 \%$ purity. All the isotopically labeled internal standards were purchased from Alsachim (Illkirch Graffenstaden, France) apart from $\left({ }^{2} \mathrm{H}_{9}\right)$-TMP which was purchased from Sigma-Aldrich (Steinheim, Germany). HPLC grade acetonitrile and methanol were purchased from Merck (Darmstadt, Germany), ammonium hydroxide (25\%) solution was purchased from Merck (Overijse, Belgium), formic acid and formic acid (98\%) from Fluka (Munich, Germany). Stock solutions and the working standards were prepared and stored at $+4{ }^{\circ} \mathrm{C}$ in amber vials.

\subsection{Sample Cleanup and Pre-Concentration}

Environmental sample cleanup and pre-concentration for aqueous samples was carried out following the protocol described by Ngumba et al., (2016) [14] without modifications. The river sediment samples were analyzed by the method described elsewhere with some modifications [15].

Briefly, $1 \mathrm{~g}$ of dried sediment was weighed into a $50 \mathrm{~mL}$ centrifuge tube (VWR), spiked with $40 \mu \mathrm{L}$ of $10 \mathrm{mg} \mathrm{L}^{-1}$ mixture of isotopically labeled internal standards, and allowed to equilibrate for $\sim 30 \mathrm{~min}$ at room temperature. Extracting solvent (methanol:water, 80:20) was added $(6 \mathrm{~mL})$ to the mixture and vortexed for one minute. The mixture was sonicated for $20 \mathrm{~min}$ using a ultrasonic bath sonicator, VWR USC 1200TH, Leicestershire, UK. Extracts were centrifuged at $4500 \mathrm{rpm}$ with SANYO HARRIER18/80, London, UK for $10 \mathrm{~min}$ and the supernatant collected in a $15 \mathrm{~mL}$ glass Kimax ${ }^{\circledR}$ test tubes. A repeat extraction using $6 \mathrm{~mL}$ of $100 \%$ methanol was done and extracts were combined into the $15 \mathrm{~mL}$ tube. Evaporation under a stream of nitrogen to approximately $1 \mathrm{~mL}$ followed and reconstituted to $10 \mathrm{~mL}$ using milli-Q water. The reconstituted sample cleanup followed the protocol described by Ngumba et al., 2016 [16] for surface and wastewater samples.

\subsection{Instrumental Analysis}

An isotope dilution method was employed in the analysis of all the target compounds. Eight-point calibration curves were prepared for each analyte by plotting response ratio of the peak area of analyte divided by peak area of internal standard ( $y$-axis) against concentration ratio of the analyte divided by concentration of internal standard ( $x$-axis). The multiple reaction monitoring parameters are shown in Table 2.

APIs were analyzed using a Quattro micro tandem mass spectrometer interfaced with a waters alliance 2975 liquid chromatograph (LC, Milford, MA, USA). The $\mathrm{C}_{18}$ reversed-phase column used was $\left(3.5 \mu \mathrm{m} \times 2.1 \mathrm{~mm} \times 100 \mathrm{~mm}\right.$ Xbridge $\left.{ }^{\mathrm{TM}}\right)$ fitted with a $2.1 \mathrm{~mm} \times 5 \mathrm{~mm}$ Vanguard ${ }^{\circledR}$ and pre-column was used for separation. Gradient elution method with Formic acid $(0.1 \%)$ in water and acetonitrile $(100 \%)$ was used as the mobile phase. Multiple reaction monitoring (MRM) in positive ion mode was used for the determination of the analytes. The multiresidue method for trace level analysis of antibiotics and antiretroviral drugs previously published in our research group by Ngumba, Kosunen et al. (2016) [16] was used without modification. 
Table 2. The multiple reaction monitoring parameters. SMX = sulfamethoxazole, CIP = ciprofloxacin, $\mathrm{TMP}=$ trimethoprim, $\mathrm{NOR}=$ norfloxacin, $\mathrm{ZDV}=$ zidovidine, $3 \mathrm{TC}=$ lamivudine, $\mathrm{NVP}=$ nevirapine.

\begin{tabular}{|c|c|c|c|c|}
\hline Target Compound & $\mathrm{RT}^{\mathrm{a}}$ & $\begin{array}{c}\text { Precursor Ion }[M+H]^{+} \\
(m / z)(C V)^{b}\end{array}$ & $\begin{array}{l}\text { Quantifier Ion } \\
(\mathrm{m} / \mathrm{z})(\mathrm{CE})^{\mathrm{c}}\end{array}$ & Qualifier Ion (CE) \\
\hline $3 \mathrm{TC}$ & 1.5 & $229.9(17)$ & $112.0(18)$ & $95.0(29)$ \\
\hline ZDV & 2.3 & $268.2(16)$ & $127.0(17)$ & $110.1(25)$ \\
\hline NVP & 4.1 & $267.2(40)$ & $226.2(29)$ & $198(29)$ \\
\hline CIP & 2.2 & $332.1(34)$ & $288.0(19)$ & $314.1(19)$ \\
\hline TMP & 2.2 & $291.1(34)$ & $123.0(19)$ & $230.0(19)$ \\
\hline NOR & 2.1 & $320.3(30)$ & $276.0(18)$ & $302.0(25)$ \\
\hline SMX & 5.1 & $254.0(28)$ & $156.0(18)$ & $108.0(17)$ \\
\hline
\end{tabular}

${ }^{\mathrm{a}} \mathrm{RT}$ retention time. ${ }^{\mathrm{b}} \mathrm{CV}$ collision voltage ${ }^{\mathrm{c}} \mathrm{CE}$ collision energy.

\section{Results}

\subsection{Instrumental Analysis Results}

Table 3 shows the LC-MS/MS-ESI method qualification results. All the target compounds were detected in all the samples with the limit of detection ranging between $3 \mathrm{ng} \mathrm{L}^{-1}$ and $18 \mathrm{ng} \mathrm{L}^{-1}$.

Table 3. LC-MS/MS-ESI method qualification results. API = active pharmaceutical ingredient, ILIS = isotopically labelled internal standard, $\mathrm{DF}=$ detection frequency, $\mathrm{LOQ}=$ limit of quantification, $\mathrm{SMX}=$ sulfamethoxazole, $\mathrm{CIP}=$ ciprofloxacin, TMP = trimethoprim, NOR = norfloxacin, $\mathrm{ZDV}=$ zidovidine, 3TC = lamivudine, NVP = nevirapine.

\begin{tabular}{cccccc}
\hline API & ILIS & $\mathbf{r}^{\mathbf{2}}$ & \% Recovery (RSD) & DF (\%) & LOQ ng L \\
\hline NOR & $\left({ }^{2} \mathrm{H}_{8}\right)-\mathrm{CIP}$ & 0.996 & $92.6(3.2)$ & 100 & 12 \\
\hline TMP & $\left({ }^{2} \mathrm{H}_{9}\right)-\mathrm{TMP}$ & 0.999 & $111.3(4.1)$ & 100 & 9 \\
\hline CIP & $\left({ }^{2} \mathrm{H}_{8}\right)-\mathrm{CIP}$ & 0.993 & $84.3(8.3)$ & 100 & 10 \\
\hline SMX & $\left({ }^{2} \mathrm{H}_{4}\right)-\mathrm{SMX}$ & 0.997 & $101(7.2)$ & 100 & 17 \\
\hline $3 \mathrm{TC}$ & $\left({ }^{13} \mathrm{C}^{2} \mathrm{H}_{2}{ }^{15} \mathrm{~N}_{2}\right)-3 \mathrm{TC}$ & 0.993 & $98.8(3.7)$ & 100 & 15 \\
\hline ZDV & $\left({ }^{13} \mathrm{C}^{2} \mathrm{H}_{3}\right)-\mathrm{ZDV}$ & 0.988 & $98.7(19.4)$ & 100 & 53 \\
\hline NVP & $\left({ }^{2} \mathrm{H}_{4}\right)-\mathrm{NVP}$ & 0.989 & $87.7(9.3)$ & 100 & 19 \\
\hline
\end{tabular}

\subsection{Occurrence of API Cocktails in the Effluent, SPM, Surface Water and River Sediments}

Prevalence of antibiotics and antiretroviral drug cocktails in the effluent, effluent SPM, surface waters and sediments are shown Table 4, respectively. In the antibiotic category, SMX was predominant in the aqueous phase with a concentration range of $96 \mu \mathrm{g} \mathrm{L}^{-1}$ and $142 \mu \mathrm{g} \mathrm{L}^{-1}$ measured approximately $500 \mathrm{~m}$ upstream and downstream to the effluent discharge point. ARVDs were also ubiquitously present in the aqueous samples with 3TC occurring twice as much as SMX in the surface waters. The concentration of APIs in the effluent discharged into the river ranged between $1.4 \mu \mathrm{g} \mathrm{L}^{-1}$ and 956.4 $\mu \mathrm{g} \mathrm{L}^{-1}$ with 3TC and SMX having the highest concentration. APIs in the effluent SPM and the river sediments occurred in $\mu \mathrm{g} \mathrm{kg}^{-1}$ to $\mathrm{mg} \mathrm{kg}^{-1}$ levels as shown in Table 4 . These results indicate the effluent SPM is the major pathway for emission of APIs from the WWTP into the receiving water.

Data from the two sampling campaigns showed significant variability, with SMX and 3TC dominating. This could mainly be attributed to the drought situation during the September sampling, whereby the receiving river was almost drying up. The seasonal variation of the January and September sampling campaign results are illustrated in Figure 1. 
Table 4. Prevalence of antibiotics and antiretroviral cocktails in effluent, SPM, surface water and river sediments in the September sampling. SPM = suspended particulate matter, SMX = Sulfamethoxazole, $\mathrm{CIP}=$ ciprofloxacin, $\mathrm{TMP}=$ trimethoprim, $\mathrm{NOR}=$ norfloxacin, $\mathrm{ZDV}=$ zidovidine, $3 \mathrm{TC}=$ lamivudine, $\mathrm{NVP}=$ nevirapine. $(\mathrm{sd}, \mathrm{n}=3) \mathrm{PNEC}=$ compound specific predicted no effect concentration for antimicrobial resistance selection, $\mathrm{n} . \mathrm{a}=$ Not available.

\begin{tabular}{|c|c|c|c|c|c|c|c|}
\hline \multirow{2}{*}{ Compound } & \multirow{2}{*}{$\begin{array}{c}\text { Effluent } \\
\text { Aqueous Phase } \\
\mu \mathrm{g} \mathrm{L}^{-1}\end{array}$} & \multirow{2}{*}{$\begin{array}{c}\begin{array}{c}\text { Effluent SPM } \\
\text { Phase }\end{array} \\
\mu \mathrm{g} \mathrm{kg}^{-1}\end{array}$} & \multicolumn{2}{|c|}{ Water $\mu \mathrm{g} \mathrm{L}^{-1}$} & \multicolumn{2}{|c|}{ Sediments $\mu \mathrm{g} \mathrm{kg}^{-1}$} & \multirow{2}{*}{$\begin{array}{c}\text { PNEC [15] } \\
\mu \mathrm{g} \mathrm{L}^{-1}\end{array}$} \\
\hline & & & $\begin{array}{l}\text { Upstream } \\
500 \mathrm{M}\end{array}$ & $\begin{array}{c}\text { Downstream } \\
500 \mathrm{M}\end{array}$ & $\begin{array}{l}\text { Upstream } \\
500 \mathrm{M}\end{array}$ & $\begin{array}{c}\text { Downstream } \\
500 \mathrm{M}\end{array}$ & \\
\hline NOR & $4.2(0.8)$ & 82,267 (559) & $1.6(0.4)$ & $4.9(1.2)$ & $776(22)$ & $248(35)$ & 0.5 \\
\hline TMP & $15.8(1.1)$ & 3080 (845) & $3.8(1.2)$ & $4.4(1.5)$ & $11(3.2)$ & $90(19)$ & 0.5 \\
\hline $\mathrm{CIP}$ & $5.3(0.6)$ & $5017(344)$ & $2.5(0.9)$ & $2.8(1.1)$ & $4125(236)$ & $1275(67)$ & 0.064 \\
\hline SMX & $956.4(9.4)$ & $23,448(1959)$ & $96.9(4.6)$ & $142.6(8.3)$ & $542(13)$ & $896(25)$ & 16 \\
\hline $3 \mathrm{TC}$ & $847.1(25.3)$ & $69,681(5824)$ & $219.6(16.9)$ & $228.3(11)$ & $491(18.2)$ & 107 (12) & n.a \\
\hline ZDV & $1.4(1)$ & 3336 (119) & $2.1(1.3)$ & $1.1(0.9)$ & $510(40)$ & $118(18)$ & n.a \\
\hline NVP & $9.5(2.2)$ & 3214 (146) & $0.9(0.4)$ & $2.3(1)$ & $95(14)$ & $101(11)$ & n.a \\
\hline
\end{tabular}

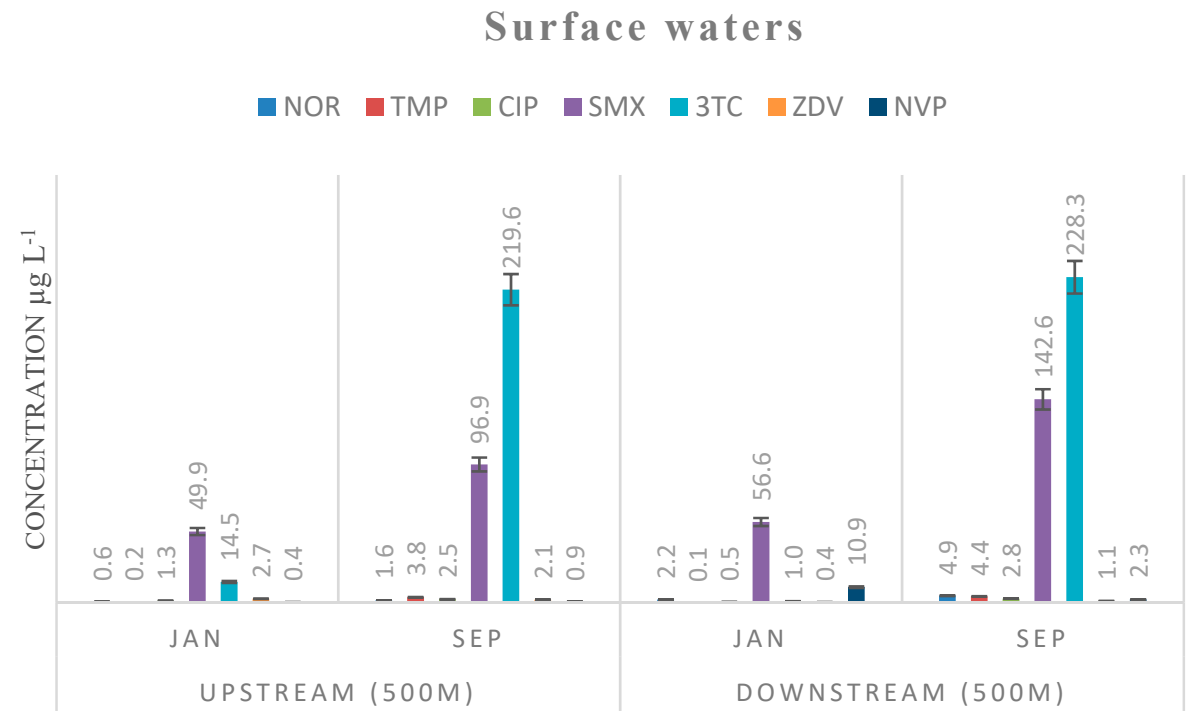

Figure 1. Seasonal variation of APIs in surface waters.

\section{Discussion}

\subsection{Cocktails of APIs in the Natural Environment within Low- and Medium-Income Countries}

This study confirms the presence of antibiotic and ARVD cocktails in the environmental samples. Concentrations of sulfamethoxazole (SMX), ciprofloxacin (CIP), trimethoprim (TMP), norfloxacin (NOR), zidovidine (ZDV), lamivudine (3TC) and nevirapine (NVP) in surface water and sediments were analyzed using a robust LC-ESI-MS/MS method. Ubiquitous detection of the all target APIs in all the collected representative samples was reported. This indicates the emission of substantial amounts of the residual antibiotics and ARVDs into the environment within the sampling areas and especially through the SPM. The measured concentrations of APIs upstream of the WWTP discharge point signifies non-point loading. Furthermore, effluent from WWTPs are considered point sources of APIs because they cannot completely remove pharmaceuticals and other personal care products within the treatment process $[17,18]$. Sorption of API to the SPM within the WWTP effluent is a pathway of emission of hydrophobic micropollutants to surface waters and river sediments. Active ingredients adsorbed into the SPM enriches the sediments. Resuspension of adsorbed compounds into the aqueous phase due to biotic and abiotic activity can maintain pseudo persistency of organic micropollutants $[19,20]$.

This can particularly occur in WWTPs where removal of sludge does not exist. The accumulated and formed sludge decomposes and the nutrients and recalcitrant matter ends up as effluent and thus 
spills into the receiving water bodies [21]. Other point sources include directly discharged human waste into the water bodies, because ingested drugs do not metabolize fully in the body and excretion occurs in urine and fecal matter as a parent compound or active metabolites [22,23].

The relatively higher concentration levels of APIs measured upstream of the effluent discharge point compared to the downstream samples could be attributed to the direct discharge of untreated wastewater into water bodies from informal settlements, illegal health clinics or from veterinary use. Furthermore, effluent from the WWTP is a major emission source of API into the receiving waters, with the SPM phase accounting for the bulk of the APIs emitted into the receiving waters as compared to the aqueous phase. Reduced flow rates of the surface waters due to drought in the sampling area in September indicates a lack of sufficient dilution of the WWTP effluent, thereby recording relatively high concentrations downstream of the discharge point. In most of the Kenyan towns, the centralized sewerage system covers $7.6 \%$ of the population, with the rest of the population using other sanitation solutions such as pit latrines [12]. Rapidly developing informal settlements within urban towns without a proper sanitation system increases the probability of discharge of raw sewage to surface waters.

HIV and AIDS remain a major public health issue of concern with an estimated 770,000 global fatalities in 2018. Out of the approximate 37.9 million people living with HIV/AIDS worldwide, 25.7 million are in the African region, out of which 16.3 are on lifelong antiretroviral therapy (ART). As of 2018, Kenya had approximately 1.49 million patients of which 75\% were on ART, while in the same period South Africa had 7.7 million patients with approximately $62 \%$ of adults on ART. [24,25]. In 2015, it was estimated that $159,000 \mathrm{Kg}$ of ARVDs reach water bodies annually in South Africa [26]. Prevalence of ARVDs in South African surface waters, ranging between $0.407 \mu \mathrm{g} \mathrm{L}^{-1}$ to $0.973 \mu \mathrm{g} \mathrm{L}{ }^{-1}$ [27], $0.003 \mu \mathrm{g} \mathrm{L}-1$ to $0.0067 \mu \mathrm{g} \mathrm{L}^{-1}$ [26] and $0.0046 \mu \mathrm{g} \mathrm{L}^{-1}$ to $34 \mu \mathrm{g} \mathrm{L} \mathrm{L}^{-1}$ [28] was reported.

Recent studies done in Kenyan surface waters have reported concentration values ranging from $6 \mu \mathrm{g} \mathrm{L}^{-1}$ to $167 \mu \mathrm{g} \mathrm{L}^{-1}$ [29], 0.5 to $1 \mu \mathrm{g} \mathrm{L}^{-1}$ [30] and $0.5 \mu \mathrm{g} \mathrm{L}^{-1}$ to $7.6 \mu \mathrm{g} \mathrm{L}^{-1}$ [14] for ZDV, NVP and 3TC. These results were in the same order of magnitude as the results reported in this study. Although environmental data on residual API is still scanty in developing countries, results reported by other recent studies done elsewhere on the African continent are shown in Table 5.

Table 5. Occurrence of antibiotic and antiretroviral drug residues in selected African surface waters and WWTP effluents. $\angle \mathrm{LOQ}=$ below limit of quantification, $<\mathrm{MQL}=$ below method quantification limit, n.d. = not detected.

\begin{tabular}{|c|c|c|c|c|c|}
\hline Category & Compound & Sample & $\begin{array}{l}\text { Concentration } \\
\text { Range } \mu \mathrm{g} \mathrm{L}^{-1}\end{array}$ & Country & Ref. \\
\hline \multirow{15}{*}{ Antibiotics } & \multirow{7}{*}{ Sulfamethoxazole } & surface waters & $<$ LOQ to 9.64 & Ghana & \multirow{4}{*}{ [31] } \\
\hline & & surface waters & $<$ LOQ to 49.56 & Kenya & \\
\hline & & surface waters & 0.511 to 53.83 & Mozambique & \\
\hline & & surface waters & 0.0033 to 10.57 & South Africa & \\
\hline & & surface waters & 11.25 & Kenya & [32] \\
\hline & & effluent/surface water & $<\mathrm{MQL}$ to 0.019 & Egypt & [33] \\
\hline & & surface water & $<0.01$ to 1.5 & Nigeria & [34] \\
\hline & \multirow{7}{*}{ Trimethoprim } & surface waters & 0.014 to 1.37 & Ghana & \multirow{4}{*}{ [31] } \\
\hline & & surface waters & $<\mathrm{LOQ}$ to 11.38 & Kenya & \\
\hline & & surface waters & 0.31 to 6.22 & Mozambique & \\
\hline & & surface waters & 0.004 to 5.88 & South Africa & \\
\hline & & surface water & 3.35 & Kenya & [32] \\
\hline & & surface water & $<0.01$ to 0.4 & Nigeria & [34] \\
\hline & & effluent/surface water & 0.21 to 1.06 & Egypt & [33] \\
\hline & Ciprofloxacin & surface water & 0.51 to 14.33 & South Africa, Ghana, Kenya & [17] \\
\hline
\end{tabular}


Table 5. Cont

\begin{tabular}{|c|c|c|c|c|c|}
\hline Category & Compound & Sample & $\begin{array}{l}\text { Concentration } \\
\text { Range } \mu \mathrm{g} \mathrm{L}^{-1}\end{array}$ & Country & Ref. \\
\hline \multirow{6}{*}{ ARVDs } & \multirow{2}{*}{ Zidovudine } & effluent/surface water & n.d. to 5.3 & South Africa & [35] \\
\hline & & effluent & 12.1 to 20.13 & Kenya & [36] \\
\hline & \multirow{2}{*}{ Nevirapine } & effluent/surface water & $<$ LOQ to 0.28 & South Africa & [35] \\
\hline & & effluent & 0.0053 to 3.3 & Kenya & [36] \\
\hline & \multirow{2}{*}{ Lamivudine } & effluent/surface water & 0.13 to 20.93 & South Africa & [35] \\
\hline & & effluent & 0.0325 to 60.68 & Kenya & [36] \\
\hline
\end{tabular}

\subsection{Risk of APIs in the Environment}

Measured environmental concentrations of APIs shown are above the compound-specific no-effect concentrations and thus can affect non-target environmental microorganisms and aquatic life [13]. This could result in mediation of resistance selection in pathogenic microorganisms within the natural environment, resulting in antibiotic resistant bacteria (ARB) and antibiotic resistant genes (ARG). WWTPs were identified as point sources of ARBs and ARGs [37]. Antimicrobial resistance is a threat to global public health and can affect anybody in any part of the world. Resistant pathogens developed in the natural environment are harder to treat using available antimicrobials, and hence their infections can lead to an increased cost of treatment, lengthy hospitalization periods and eventually death. Pharmaceutical mixtures within the environment can have additive effects even though the risk of individual compounds could be negligible. For instance, antibiotic drug combinations designed to work synergistically, such as TMP-SMX (co-trimoxazole) with a combination ratio of 1:5 [38]. These combination ratios can also exist within natural environments, where their synergistic activity continues to act in the environmental microorganism, a precursor for antimicrobial resistance selection. Measured environmental concentrations in this study were consistently higher in the river sediment phase as compared to the surface water. This could mean that the risk of resistance selection could be greatest in the sediment phase [14]. These phases were commonly overlooked in previous studies.

Similarly to bacteria, viruses can evolve resistance against antiviral drugs, especially in instances where there is a co-existence of the virus to be treated with the antiviral drug [36]. More studies on the development of antiviral resistance is needed. Resistant infections kill approximately 58,000 newborn children in India every year [39]. Over 2.8 million resistant infections occur yearly in the United States of America, resulting in over 35,000 deaths each year [40]. In Kenya, approximately 50,000 people die each year due to multidrug-resistant tuberculosis [41]. At a time when antimicrobial resistance causes major problems in healthcare and new viral diseases emerge, it is central to understand antimicrobial contamination in the environment.

\section{Conclusions}

This study determined the prevalence and concentration of antibiotic and antiretroviral drug cocktails in the effluent, SPM, surface waters and river sediments of selected sampling areas in Kenya. To the best of our knowledge, this is the first study to report the occurrence of APIs in the SPM phase within Kenyan WWTP effluents. The results indicate that SPM is an important phase for consideration in the determination of emission of micropollutants from WWTPs. Surface waters and sediments were found to be contaminated with elevated levels of the target compounds. APIs in the environment can have effects on public health on a global scale. Decentralized sanitation solutions, especially in informal settlements in the peri-urban areas, can help mitigate the direct discharge of raw sewage into surface waters. Sustainable sanitation solutions aimed at separating the urine at source are recommended, since urine is a point source of human pharmaceuticals. 
Author Contributions: Conceptualization, T.T. and A.G.; methodology, E.N and T.T.; software, E.N; validation, T.T., L.-R.S., A.G and E.N.; formal analysis, P.K.; investigation, P.K.; resources, T.T.; data curation, E.N and L.-R.S.; writing-original draft preparation, P.K.; writing—review and editing, T.T, L.-R.S., A.G and E.N.; visualization, P.K.; supervision, L.-R.S., A.G and T.T.; project administration, T.T.; funding acquisition, T.T., L.-R.S., and A.G. All authors have read and agreed to the published version of the manuscript.

Funding: This research was funded by the University of Jyväskylä doctoral program in the Department of Biological and Environmental Sciences, the Academy of Finland grant number 314939 and by Jane and Aatos Erkko Foundation.

Acknowledgments: We acknowledge the technical support of Mervi Kosunen, Emma Pajunen and Martin Murigi during sample collection and analysis. We thank the Machakos water and sewerage company (MACHWASCO) for assistance during sample collection.

Conflicts of Interest: The authors declare no conflict of interest.

\section{References}

1. Vasquez, M.I.; Lambrianides, A.; Schneider, M.; Kümmerer, K.; Fatta-Kassinos, D. Environmental side effects of pharmaceutical cocktails: What we know and what we should know. J. Hazard. Mater. 2014, 169-189. [CrossRef] [PubMed]

2. Kümmerer, K. Pharmaceuticals in the Environment: Sources, Fate, Effects and Risks; Springer: Berlin, Germany, 2008; Volume 1. [CrossRef]

3. Kümmerer, K. Antibiotics in the aquatic environment-A review-Part I. Chemosphere 2009, 75, 417-434. [CrossRef] [PubMed]

4. Tambosi, J.L.; Yamanaka, L.Y.; José, H.J.; De Fátima Peralta Muniz Moreira, R.; Schröder, H.F. Recent research data on the removal of pharmaceuticals from sewage treatment plants (STP). Quim. Nova 2010, 33, 411-420. [CrossRef]

5. Tran, N.H.; Chen, H.; Reinhard, M.; Mao, F.; Yew-Hoong Gin, K. Occurrence and removal of multiple classes of antibiotics and antimicrobial agents in biological wastewater treatment processes. Water Res. 2016, 104, 461-472. [CrossRef] [PubMed]

6. Carvalho, I.T.; Santos, L. Antibiotics in the aquatic environments: A review of the european scenario. Environ. Int. 2016, 94, 736-757. [CrossRef] [PubMed]

7. Pereira, A.; Silva, L.; Laranjeiro, C.; Lino, C.; Pena, A. Selected pharmaceuticals in different aquatic compartments: Part I-Source, fate and occurrence. Molecules 2020, 25, 1026. [CrossRef]

8. Gullberg, E.; Cao, S.; Berg, O.G.; Ilbäck, C.; Sandegren, L.; Hughes, D.; Andersson, D.I. Selection of resistant bacteria at very low antibiotic concentrations. PLoS Pathog. 2011, 7, e1002158. [CrossRef]

9. Yakubu, O.H. Pharmaceutical wastewater effluent-source of contaminants of emerging concern: Phytotoxicity of metronidazole to soybean (Glycine Max). Toxics 2017, 5, 10. [CrossRef]

10. Sharma, V.K.; Johnson, N.; Cizmas, L.; McDonald, T.J.; Kim, H. A review of the influence of treatment strategies on antibiotic resistant bacteria and antibiotic resistance genes. Chemosphere 2016, 150, 702-714. [CrossRef]

11. Larsen, T.A.; Maurer, M.; Udert, K.M.; Lienert, J. Nutrient cycles and resource management: Implications for the choice of wastewater treatment technology. Water Sci. Technol. 2007, 56, 229-237. [CrossRef]

12. KNBS. 2019 Kenya Population and Housing Census: Volume IV-Distibution of Population by Socio-Economic Characteristics; KNBS: Nairobi, Kenya, 2019.

13. Kairigo, P.; Ngumba, E.; Sundberg, L.; Gachanja, A.; Tuhkanen, T. Occurrence of antibiotics and risk of antibiotic resistance evolution in selected Kenyan wastewaters, surface waters and sediments. Sci. Total Environ. 2020, 720, 137580. [CrossRef] [PubMed]

14. Ngumba, E.; Anthony, G.; Tuhkanen, T. Occurrence of selected antibiotics and antiretroviral drugs in Nairobi River Basin, Kenya. Sci. Total Environ. 2016, 539, 206-213. [CrossRef] [PubMed]

15. Subedi, B.; Balakrishna, K.; Joshua, D.I.; Kannan, K. Mass loading and removal of pharmaceuticals and personal care products including psychoactives, antihypertensives, and antibiotics in two sewage treatment plants in Southern India. Chemosphere 2017, 167, 429-437. [CrossRef] [PubMed]

16. Ngumba, E.; Kosunen, P.; Gachanja, A.; Tuhkanen, T. A multiresidue analytical method for trace level determination of antibiotics and antiretroviral drugs in wastewater and surface water using spe-lc-ms $/ \mathrm{ms}$ and matrix-matched standards. Anal. Methods 2016, 8, 6720-6729. [CrossRef] 
17. Danner, M.-C.; Robertson, A.; Behrends, V.; Reiss, J. Antibiotic pollution in surface fresh waters: Occurrence and effects. Sci. Total Environ. 2019, 664, 793-804. [CrossRef] [PubMed]

18. Fatta-Kassinos, D.; Meric, S.; Nikolaou, A. Pharmaceutical residues in environmental waters and wastewater: Current state of knowledge and future research. Anal. Bioanal. Chem. 2011, 399, 251-275. [CrossRef]

19. Archer, E.; Petrie, B.; Kasprzyk-Hordern, B.; Wolfaardt, G.M. The fate of pharmaceuticals and personal care products (PPCPS), endocrine disrupting contaminants (EDCS), metabolites and illicit drugs in a wwtw and environmental waters. Chemosphere 2017, 174, 437-446. [CrossRef]

20. Lindberg, R.H.; Wennberg, P.; Johansson, M.I.; Tysklind, M.; Andersson, B.A.V. Screening of human antibiotic substances and determination of weekly mass flows in five sewage treatment plants in Sweden. Environ. Sci. Technol. 2005, 39, 3421-3429. [CrossRef]

21. Ignatev, A.; Tuhkanen, T. Monitoring WWTP performance using size-exclusion chromatography with simultaneous uv and fluorescence detection to track recalcitrant wastewater fractions. Chemosphere 2019, 214, 587-597. [CrossRef]

22. Michael, I.; Rizzo, L.; McArdell, C.S.; Manaia, C.M.; Merlin, C.; Schwartz, T.; Dagot, C.; Fatta-Kassinos, D. Urban wastewater treatment plants as hotspots for the release of antibiotics in the environment: A review. Water Res. 2013, 47, 957-995. [CrossRef]

23. Kümmerer, K. Antibiotics in the aquatic environment-A review-Part II. Chemosphere 2009, 75, $435-441$. [CrossRef] [PubMed]

24. World Health Organization. WHO|HIV/AIDS. Available online: https://www.who.int/gho/hiv/en/ (accessed on 22 March 2019).

25. World Health Organization. WHO|Antiretroviral Therapy (ART) Coverage among All Age Groups. Available online: https://www.who.int/gho/hiv/epidemic_response/ART/en/ (accessed on 22 March 2019).

26. Swanepoel, C.; Bouwman, H.; Pieters, R.; Bezuidenhout, C. Presence, Concentrations and Potential Implications of Hiv-Anti-Retrovirals in Selected Water Resources in South Africa; Water Research Commission: Pretoria, South Africa, 2015.

27. Wood, T.P.; Duvenage, C.S.J.; Rohwer, E. The occurrence of anti-retroviral compounds used for HIV treatment in south african surface water. Environ. Pollut. 2015, 199, 235-243. [CrossRef] [PubMed]

28. Ncube, S.; Madikizela, L.M.; Chimuka, L.; Nindi, M.M. Environmental fate and ecotoxicological effects of antiretrovirals: A current global status and future perspectives. Water Res. 2018, 145, 231-247. [CrossRef] [PubMed]

29. K'oreje, K.O.; Vergeynst, L.; Ombaka, D.; De Wispelaere, P.; Okoth, M.; Van Langenhove, H.; Demeestere, K. Occurrence patterns of pharmaceutical residues in wastewater, surface water and groundwater of Nairobi and Kisumu City, Kenya. Chemosphere 2016, 149, 238-244. [CrossRef] [PubMed]

30. Kandie, F.J.; Krauss, M.; Beckers, L.M.; Massei, R.; Fillinger, U.; Becker, J.; Liess, M.; Torto, B.; Brack, W. Occurrence and risk assessment of organic micropollutants in freshwater systems within the Lake Victoria South Basin, Kenya. Sci. Total Environ. 2020, 714, 136748. [CrossRef] [PubMed]

31. Segura, P.A.; Takada, H.; Correa, J.A.; El Saadi, K.; Koike, T.; Onwona-Agyeman, S.; Ofosu-Anim, J.; Sabi, E.B.; Wasonga, O.V.; Mghalu, J.M.; et al. Global occurrence of anti-infectives in contaminated surface waters: Impact of income inequality between countries. Environ. Int. 2015, 80, 89-97. [CrossRef]

32. Bagnis, S.; Boxall, A.; Gachanja, A.; Fitzsimons, M.; Murigi, M.; Snape, J.; Tappin, A.; Wilkinson, J.; Comber, S. Characterization of the Nairobi River catchment impact zone and occurrence of pharmaceuticals: Implications for an impact zone inclusive environmental risk assessment. Sci. Total Environ. 2020, 703. [CrossRef] [PubMed]

33. Abou-Elwafa Abdallah, M.; Nguyen, K.H.; Ebele, A.J.; Atia, N.N.; Ali, H.R.H.; Harrad, S. A single run, rapid polarity switching method for determination of 30 pharmaceuticals and personal care products in waste water using Q-Exactive Orbitrap high resolution accurate mass spectrometry. J. Chromatogr. A 2019, 1588, 68-76. [CrossRef]

34. Oluwatosin, O.; Adekunle, B.; Obih, U.; Arne, H. Quantification of pharmaceutical residues in wastewater impacted surface waters and sewage sludge from Lagos, Nigeria. J. Environ. Chem. Ecotoxicol. 2016, 8, 14-24. [CrossRef]

35. Madikizela, L.M.; Ncube, S.; Chimuka, L. Analysis, Occurrence and removal of pharmaceuticals in african water resources: A current status. J. Environ. Manag. 2020, 253, 109741. [CrossRef] 
36. Nannou, C.; Ofrydopoulou, A.; Evgenidou, E.; Heath, D.; Heath, E.; Lambropoulou, D. Antiviral drugs in aquatic environment and wastewater treatment plants: A review on occurrence, fate, removal and ecotoxicity. Sci. Total Environ. 2020, 134322. [CrossRef] [PubMed]

37. Sabri, N.A.; Schmitt, H.; Van der Zaan, B.; Gerritsen, H.W.; Zuidema, T.; Rijnaarts, H.H.M.; Langenhoff, A.A.M. Prevalence of antibiotics and antibiotic resistance genes in a wastewater effluent-receiving river in the Netherlands. J. Environ. Chem. Eng. 2018, 102245. [CrossRef]

38. Vilchèze, C.; Jacobs, W.R. The combination of sulfamethoxazole, trimethoprim, and isoniazid or rifampin is bactericidal and prevents the emergence of drug resistance in mycobacterium tuberculosis. Antimicrob. Agents Chemother. 2012, 56, 5142-5148. [CrossRef] [PubMed]

39. Laxminarayan, R.; Duse, A.; Wattal, C.; Zaidi, A.K.M.; Wertheim, H.F.L.; Sumpradit, N.; Vlieghe, E.; Hara, G.L.; Gould, I.M.; Goossens, H.; et al. Antibiotic resistance-the need for global solutions. Lancet Infect. Dis. 2013, 1057-1098. [CrossRef]

40. CDC. Antibiotic Resistance Threats in the United States; Center for Disease Control and Prevention: Atlanta, GA, USA, 2019. [CrossRef]

41. WHO. Global Tuberculosis Report 2017; WHO: Geneva, Switzerland, 2017.

(C) 2020 by the authors. Licensee MDPI, Basel, Switzerland. This article is an open access article distributed under the terms and conditions of the Creative Commons Attribution (CC BY) license (http://creativecommons.org/licenses/by/4.0/). 